\title{
CITY OF WALLS
}





\section{CITY OF WALLS}

Crime, Segregation, and Citizenship in São Paulo

TERESA P. R. CALDEIRA

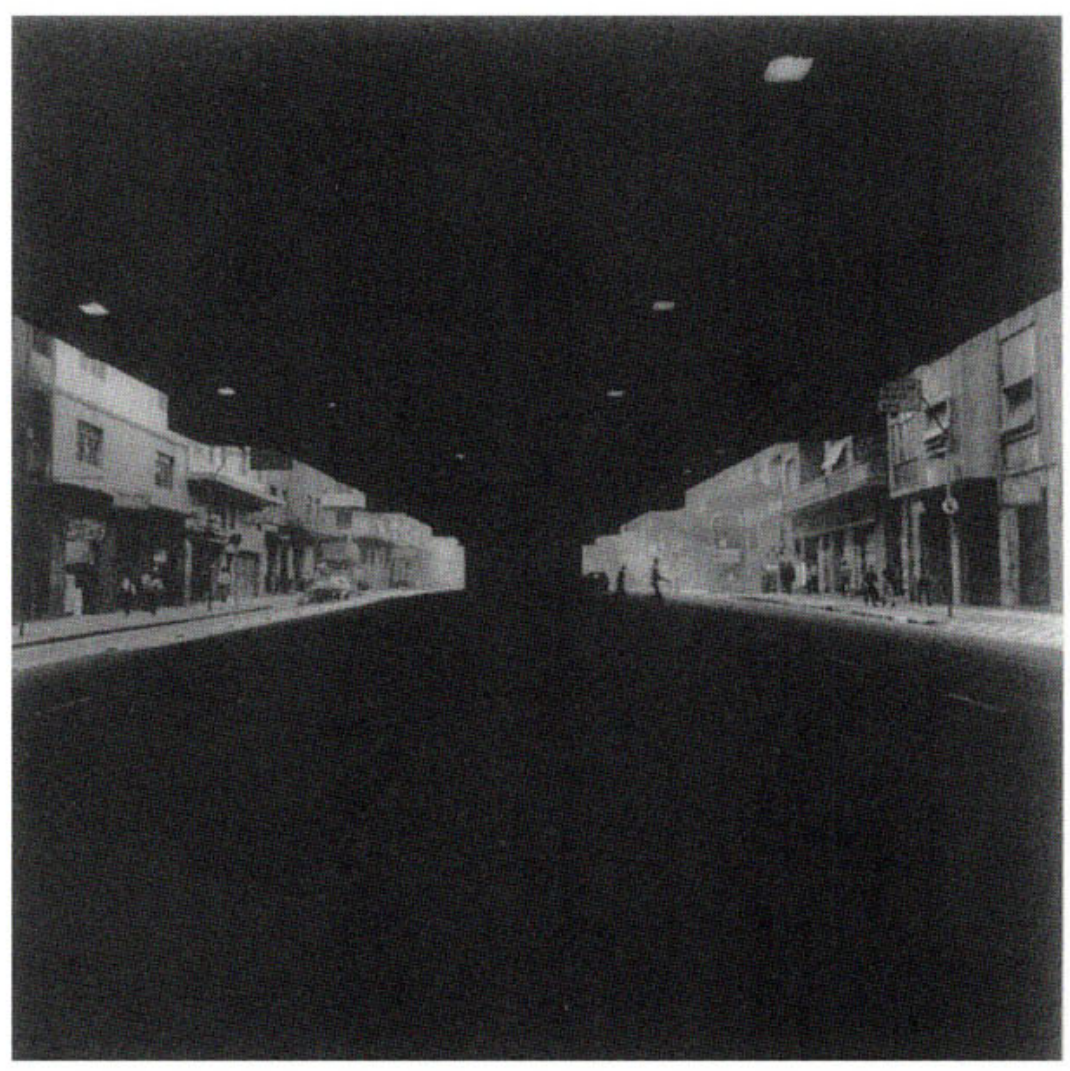

University of California Press

BERKELEY LOS ANGELES LONDON 
Title page illustration: Avenida São João, São Paulo. Photograph by Cristiano Mascaro.

University of California Press

Berkeley And Los Angeles, California

University of California Press, Ltd.

London, England

(C) 2000 by the Regents of the University of California

Library of Congress Cataloging-in-Publication Data

Caldeira, Teresa Pires do Rio.

City of walls : crime, segregation, and citizenship in São Paulo / Teresa P. R. Caldeira

p. $\quad \mathrm{cm}$.

Includes bibliographical references and index.

ISBN 978-0-520-22143-7 (pbk. : alk. paper)

1. Crime-Brazil-São Paulo. 2. Segregation-Brazil-

São Paulo. 3. Social classes-Brazil-_São Paulo. 4. São Paulo

(Brazil)-Race relations. 5. São Paulo (Brazil)-Social

conditions. 6. São Paulo (Brazil)-Politics and government.

I. Title.

HV6895.S $\mathrm{C}_{35} 2000$

$364.98 I^{\prime} 61-\mathrm{dc} 21$

$00-0287 \times 3$

CIP

Manufactured in the United States of America

$13 \quad 1211$

$12 \quad 11 \quad 10$

The paper used in this publication meets the minimum requirements of ANSI/NISO Z39 0.48-1992 (R 1997) (Permanence of Paper). 
To Jim,

explorer of cities, real and imagined 
